\title{
INDONESIA'S LEADERSHIP ROLE IN ASEAN: HISTORY AND FUTURE PROSPECTS
}

\author{
Bama Andika Putra \\ MA, University of Melbourne, AUSTRALIA, bputra@unimelb.edu.au
}

\begin{abstract}
Indonesia is perceived as a natural de facto leader of the International Organization of ASEAN since its establishment in 1967. Myriad factors have contributed towards this highly regarded position in ASEAN, including its persistence towards measures of regionalism, hence positioning ASEAN at the central core of Indonesia's foreign policies throughout the years. As one of the founding members of ASEAN, key past foreign policies have reflected an intention to shape the organization in a manner most ideal for Indonesia. Thus it is crucial to further understand in what nature and to what extent has Indonesia led ASEAN in the past, and what are Indonesia's prospects in leading ASEAN with the change of presidency that the state faces now. Based on those questions, the paper explores Indonesia's leadership role in ASEAN with focus upon Indonesia's historical role in conflict management correlated with ASEAN member states, and its capacity in architecting contemporary ASEAN institutions. It argues Indonesia's active ad hoc diplomacy in settling various security issues related to the territorial disputes over the Preah Vihear Temple between Cambodia and Thailand, and tensions in the South China Sea. It further argues Indonesia's vital role in establishing key institutions and norms including the ASEAN Political and Security Community and the ASEAN Intergovernmental Commission on Human Rights. Finally the paper focuses on Indonesia's ostensible rise, and its prospects in continuing its ASEAN leadership role under the newly elected Joko Widodo, pertinent towards the G20 and policy to reassure neighboring states of its non-belligerent rise.
\end{abstract}

Keywords: Indonesia; ASEAN; Regionalism; Leadership; Institutionalism; Southeast Asia

\section{INTRODUCTION}

The establishment of regional organizations as a result of regionalism is a concept well known by academics in the International Relations scope. With the formation of various regional organizations during the Cold War, ranging from the Organization of African Unity (African Union), European Coal and Steel Community (European Union), ASEAN (Association of Southeast Asian Nations), and many more spread throughout the different geopolitical locations, regional organizations is well known to be used by state actors to further exert their region's influence In the global community. This process of regionalism further leads to the processes and structures of region building, pertaining to closer relations on economic, political, security, and sociocultural levels (Borzel, Golternmann, Lohaus, Striebinger, 2012, p. 3). Various theories have attempted to explain the dynamics surrounding regional organizations, and despite acknowledging the surmountable influence a membership of a regional organization caters, vast majority of these theories (including Neoliberal Institutionalism, Liberal Intergovernmentalism, etc.) recognizes the central and dominant role that a state has in the institution. Just like the regional organizations listed above, it is not an uncommon 
phenomenon to see dominant state actors in the organization, in comparison to other member States, a highly evident case in ASEAN (Association of Southeast Asian Nations).

Since the establishment of ASEAN in 1967, great regional integration has been witnessed. ASEAN went from being a regional organization aimed in assuring peace and security during the cold war, becoming one of the most successful regional organizations currently existing in the International system. With greater integration to be expected in upcoming years, it has been well known that Indonesia, a powerhouse of the region even before the establishment of the organization, is the de facto leader based on various persistent measures it has taken for the sake of the organization's development. This was evident especially during the first decade of the $21^{\text {st }}$ century, leading the organization to extents impossible to be imagined if Indonesia was not part of it. Despite a huge emphasis upon ASEAN based foreign policies of Indonesia, many questions have been asked as to what extent this exerted influence of Indonesia towards ASEAN would continue under the presidency of Joko Widodo.

With an extensive amount of research on Indonesia's influence and role as a leader on the region, little attention has been focused upon towards what extent would Indonesia maintain this role of a de facto leader of ASEAN in the upcoming years (in light of the reformed Indonesian foreign policy under the newly elected president Joko Widodo). This explanatory research is analysed based on qualitative data, and uses deductive methodology approach. The research aims in answering the historical basis of Indonesia's leadership roles in ASEAN, and to analyse the future prospects of its leadership role in the organization. Results of the research predicts that with an extensive amount of leadership and influence exercised in ASEAN, Indonesia will still base their foreign policy on ASEAN centricity, despite changes of foreign policy prioritizations and the contemporary regional dynamics of the region.

\section{THEORETICAL FRAMEWORK}

In regards with integration and the formation of regional organizations, various different approaches will be relevant in explaining the process. Theories ranged from Neofunctionalism (theorizing that integration is a gradual process which is self-sustaining), Intergovernmentalism (a contemporary reality of state dominance in organizations), all the way to classic neoliberal Institutionalism which argues that the state has a certain level of compromise in achieving a collective goal through International Institutions, but of course, does not deny the very dominant existence of state actors. Through these range of International relations theories, it is fair to conclude that most International relations academics throughout the $20^{\text {th }}$ century, acknowledges the dominating existence of state actors in International Organizations.

Despite explaining the overall structure of International organizations, the concepts above fails in emphasizing the leadership role of a state in International Organizations. The writer thus leans on a classical approach of explaining regional integration through International organizations, under the Neoliberal Institutionalism, with special reference towards Charles Kindleberger's theory of hegemonic stability. Despite providing a general analysis of hegemon and the provision of the collective good of International economic stability, his theory describes perfectly, the elements of a hegemon, including dominance, leadership, and exploitation. He argues how states will exert power to produce results favoring the state, and the creation of an International regime will be highly dependent upon both the influence and participation of a single powerful state (Kindleberger, 1973, p. 243) (Emmers, 2014, p. 545).

Being adapted in various different schools of thought in International relations, Neoliberal Institutionalism also provides a certain view of the hegemonic stability theory. Neoliberals argue that the establishment of institutions would eventually favor the hegemon, but still has a leading role in the provision of International public goods (Emmers, 2014, p. 546). The various acts of cooperation found in International organization is a reflection of both the need for cooperation with mutual interests among the actors of the International organization, despite the fact that the system of arrangements are still motivated by self-interests (Keohane, 1984, p. 59-63).

The hegemonic stability theory under neoliberal institutionalism provides a great balance of how states behave under the umbrella of regional organizations, consisting of a balanced interest between cooperation and the existence of state dominance. These 2 elements are crucial to explain and predict Indonesia's foreign policy in ASEAN, starting from the establishment of the regional organization, right until the contemporary presidency of Joko Widodo. As stated by Norkevičius in 2014 that; 'State is defined as an effective gatekeeper that guards the gate between domestic and international space' (Norkevičius, 2014, p. 101). Thus the emergence of these regional organizations (including ASEAN) should be viewed based on a balanced perspective of state's self-interests, and the need to willingly cooperate based on the vast amount 
of benefits that states can acquire from the very formation of that regional organization. With the expanded influence that ASEAN has achieved throughout the years, this notion of interdependence between Indonesia and ASEAN will continue, shaping the foreign policy of Indonesia in regards with the ASEAN centricity.

\section{INDONESIA IN ASEAN: A HISTORY OF EXERTED INFLUENCE}

Southeast Asia has always been a region of both interest and concern for Indonesia. The foreign policy applied to interact with the region has varied, accustomed towards the different political dynamics that has occurred in the region. Indonesia's foreign policies has been transitioning, from the Sukarno 'Konfrontasi' (Confrontation) policy, Suharto's New World Order Government, all the way to Indonesia's post democratization era that accentuates the need of a more democratized based values for ASEAN. These policies may all be different in nature, but still have a unified aim of furthering Indonesia's position both in the region, and in ASEAN. In realizing this aim, Indonesia has adopted various policies, reflecting their role as a leader in the organization of ASEAN, and ultimately a prominent leader of the region.

\subsection{A Brief History of Indonesia's Foreign Policy towards ASEAN}

The Association of Southeast Asian Nations was established on August 8, 1967, with Indonesia included as one of the core founders of the organization along with Malaysia, Thailand, Singapore and the Philippines. Established in the mid of the cold war, the growing fear amidst the dominating and rapid spread of communism eventually led these states to establish this form of cooperation that not only gives a certain level of guarantee among the states to avoid conflict, but also can be used as an avenue to counter possible foreign threats. Before the establishment of the organization, states located in Southeast Asia held a great level of suspiciousness and fear towards Indonesia, clearly reflected after Sukarno's Konfrontasi policy, a policy threatening the planned establishment of the Federation of Malaysia. Threats emerged and the confrontation intensified, as Indonesia spread propaganda attacks through slogans including "Crush Malaysia" (Anwar, 1994, p. 23-24). It was not until Suharto's 'New Order' government that Indonesia started a peaceful engagement on relations with the Southeast Asian region, assuring that Indonesia's great power will not be abused to undermine the peace of Southeast Asia.

Since 1966, Suharto's New Order government gave an emphasis on cooperation rather than coercive action, abandoning Suharto's revolutionary and confrontational foreign policies (Sukma, 2012, p. 78) (Suryadinata, 1996, p.85). It was under Suharto's vital interest to maintain a peaceful Southeast Asian region, without the influence of both the US and the Communist states, in align with Indonesia's Non-Alignment Movement developed during the 1955 Bandung Conference, and formally established in the 1961 Belgrade Summit. The movement consisted of states that are formally not aligned with any major powers (Kumar, 1997, p. 45). Indonesia's natural, de facto leadership role in ASEAN started to be evident under Suharto's rule, successfully leading the establishment of various key peace and security agreements among the ASEAN states.

Despite ASEAN's main principle of non-interference and high regards on national sovereignty, the domination of Indonesia's presence was able to direct the organization to formulate 2 key principles which were in align with Indonesia's interests of maintaining the peace and security of the region and counter foreign threats. The first principle formed with Indonesia as the driving force was the Asian Zone for Peace, Freedom, and Neutrality (ZOPFAN) on November 27, 1971, reiterating the member's commitment to ensure stability and security from external interference in any form (ASEAN, 1971). The communist takeover of Phnom Penh, Saigon, and Laos in 1975 reflected a rapid success of the revolutionary communism in Southeast Asia. Taken by surprise, ASEAN thus established the Treaty of Amity and Cooperation (TAC) during the Bali Summit in February 1976. Based on values of state sovereignty, TAC was aimed in displaying a sense of political solidarity during the wake of revolutionary communist success in Indochina during 1975 (Liow, 1995, p. 376). TAC sets out codes of conduct for regional relations, and guidelines for the pacific settlement of disputes.

Indonesia's immense influence and power towards ASEAN was shattered following the Asian financial crisis of 1997/1998. The economic crisis that led students nationwide leading demonstrations demanding democratic reform of Indonesia's government (known as Reformasi), eventually concluded the resignation of Suharto in May 1998. Since then, Indonesia played a passive role in its foreign policy, including ASEAN. Attempts of domestic democratic reformation and the rebuild of the state's national economy occupied the then 2 governments of post-Reformasi (Abdurrahman Wahid and Megawati Sukarnoputri). It was only under the presidency of Susilo Bambang Yudhoyono (SBY), which started from 2004-2014, that Indonesia's democratization process developed in such stable rate compared to its neighbors in ASEAN, and that 
Indonesia's economy was both slowly recovering and developing. With the Ministry of Foreign Affairs Hassan Wirajuda (2001-2009) and Marty Natalegawa (2009-2014), Indonesia enacted various key foreign policies that brought them back to their strategic position in ASEAN. The contemporary foreign policy of Indonesia under SBY and Natalegawa echoes values of cooperation and peace. Basing the foreign policy priorities on 'Geographic Proximity,' Indonesia defines its inner circle priority encompassing ASEAN, second circle consisting of East Asia, while the last circle comprising the Asia Pacific region (Anwar, 2013, p.10-11). Relations with these states was based on SBY's policy of the "free and active policy", and 'Million Friends, Zero Enemies,' disapproving any assertive posture towards the International Community. The emphasis of ASEAN as the cornerstone of Indonesia's foreign policy though, was highly evident under Natalegawa's doctrine of 'Dynamic Equilibrium' a concept emphasizing to build a series of regional mechanisms driven by middle powers with no dominant or excluded actor (Poling, 2013, p. 2-4). A doctrine to help understand Indonesia's persistence in expanding the membership of ASEAN based forums and organizations, including the East Asian Summit, and the inclusion of major global powers under the ASEAN Regional Forum. This concept has led to many leadership roles undertaken by Indonesia, in forms of initiating institutional reforms of ASEAN institutions, as well as its activeness in pressing major contemporary issues faced by ASEAN member states.

\subsection{Indonesia's Contemporary Leadership Roles in ASEAN}

With the expansion of ASEAN membership becoming a total of 10 states, the region of Southeast Asia was faced with a vast climate of political dynamics. In defining the crucial role of Indonesia's leadership role in the contemporary dynamics of ASEAN, it is pivotal to firstly understand the premise of leadership in ASEAN as a concept. Rattanasevee in 2014 outlined how leadership in ASEAN is reflected by the presidency or chairmanship (rotated alphabetically each year) which is able to influence decision making process of the organization, and further explained that the only logical measurement of leadership is not through that formal process, but measured through the informal forms of leadership which possess ability to coerce other actors (Rattanasevee, 2014, 118-119). The writer acknowledges this concept of defining leadership in ASEAN, but will further extend the concept with the inclusion of the hegemonic stability theory explained previously, on how Indonesia reflects a dominant present presence, acting in a way that would provide a balanced benefit for both ASEAN and the state itself. ASEAN of course is part of Indonesia's first inner circle priority of foreign policy (early $21^{\text {st }}$ century), and Indonesia's way in exerting influence and dominance in the institution was through measures that reflected their success of democratization, and how ASEAN can be used to further Indonesia's influence outside the organization. This is displayed through 2 different measures, including Indonesia's role in conflict management involving ASEAN states, and Indonesia as an architecture of ASEAN institution and norms.

\subsubsection{Indonesia's role in conflict management among ASEAN members}

The role that Indonesia plays in conflict management reflects nothing but its intention to stabilize the political and security tensions in the region, and as a show of a well-established and developed state acting to solve tensions of its members. This is reflected through 2 major conflicts that have happened in recent years. First are the territorial disputes between Thailand and Cambodia over the Preah Vihear temple in 2011, and the issue of South China Sea between People's Republic of China and several ASEAN member States.

Tensions over the Temple of Preah Vihear started in 1958, with Thailand claiming the territorial sovereignty of the temple that the French government determined in 1907 as part of Cambodia's territory. Despite ICJ's judgment accepting Cambodia's claim over the temple, tensions reignited in 2008 after Cambodia's nomination of the temple as a UNESCO World Heritage site, with the inclusion of Thailand's territory (Traviss, 2012, p.326-327). With thousands of Thailand and Cambodian soldiers deployed in the region, military clashes lasted from 2008 until 2011.

Indonesia in response towards the re-eruptions of conflicts in early 2011, took a more active approach in comparison with the passive role taken by other ASEAN members. Indonesia's Foreign Minister Marty Natalegawa negotiated with leaders of both states during the Indonesian initiated, ASEAN Informal foreign Ministerial Meeting in Jakarta, 22 February 2011 (Widyaningsih, Robert, 2014, p.108). There was negotiation success at first, initially with both governments agreeing towards the deployment of Indonesian military and civilian observers aimed in monitoring the ceasefire agreement. Despite so, negotiation stalemate occurred, with both parties denying their early commitments in agreeing with the results of the negotiation. Military and civilian observers never were sent to the borders of Cambodia and Thailand, but after the informal foreign ministerial meetings, the disputes successfully faced a discontinuation thanks to the initial attempts of Indonesia in finding a diplomatic outcome of the territorial dispute. Though evidently not agreed upon to, 
Indonesia was able to exert its influence and its dissatisfaction towards both parties, and was able to send a clear sign of the need of both parties to restrain from hostilities.

In comparison with the Preah Vihear Temple disputes, the claims over the South China Sea reflect an evergreater security concern for Indonesia. China's claim over the South China Sea is based on its perceived 2,000 years of the islands of Spartlys, Scaborough Shoal, and Paracels being part of China's territory. Based on the United Nations Convention on the Law of the Sea (UNCLOS) 200 nautical miles Exclusive Economic Zone, China's claims over the islands further provides a stretched claim over the sea areas which are naturally the sea territorial area of Vietnam, Phillippines, Brunei, Malaysia, and to a small extent, Indonesia (Natuna Islands). China started seizing the 3 strategically located islands since the 1970s, showing a great military presence in the area (Karim, 2013, p. 99-101). Worried about possible escalations caused by the conflicting claims over the South China Sea, ASEAN in 2002 declared the Conduct of Parties in the South China Sea, declaring essential measures associated with the disputed areas, among them includes; (1) reaffirming the commitment towards the 1982 UNCLOS, (2) reaffirms the freedom of navigation, (3) parties to undertake to resolve their territorial disputes without resorting to the use of force, and (4) Parties to refrain from actions that would escalate the disputes (ASEAN, 2002). The declaration was signed by all 10-member states of ASEAN, and Mr. Wang Yi as the Special Envoy and Vice Minister of Foreign Affairs representing People's Republic of China. The declaration though did not solve any substantive issues of the disputes, and thus further influenced ASEAN In a significant manner.

Despite small claims of Indonesian territory in the South China Sea, Indonesia was among the states determined to settle or at least press down any surfaced tensions with relations to the disputed areas. It was and still is the core interest of Indonesia to maintain the overall peace and security of the region, and the disputes over South China Sea simply undermines that essential aim. Indonesia though shows great persistence and determination in making sure that ASEAN still runs in a manner agreed, despite the continuous presence of such a belligerent and assertive state known as China.

Indonesia's leadership in ASEAN was clearly reflected following ASEAN's 2012 Ministerial Meeting, in which the Foreign Minister of Cambodia (the then chair of the Summit) refused to issue a joint communique of the summit, first ever to happen in the organization. Cambodia, which that time acted as a close economic partner with China, was persistent that the recent clashes that time between Philippines and China in the South China Sea must be responded bilaterally, not multilaterally through ASEAN (this of course reflects one sided though in the part of Cambodia). Not willing to allow the failure of a joint communiqué, Natalegawa undertook rounds of consultative diplomacy formulating ASEAN's document that could be accepted by all states, which eventually a week later, resulted to the 'Six-Basic principles on the South China Sea' (which reemphasized the essential values of the 2002 Code of Conduct in South China Sea) (Emmers, 2014, p. 552-553).

\subsubsection{Indonesia as an architecture of ASEAN institution and norms}

With the revival of Indonesia's economic power and a successful transition towards democracy, Indonesia was again ready to take the leadership role in ASEAN through the establishment of various organizations in align with human rights and democracy (Garnaut, 2012, p. 14-16). The establishment of agreements and institutions that favors Indonesia is a clear reflection of not only the dominance it has in the organization, but also its persistence to influence policies favoring the state. 2 perfect examples is the establishment of the ASEAN Political and Security Community 2015, and the ASEAN Intergovernmental Commission on Human Rights, both a reflection of Indonesia's willingness to spread its successful transition towards democracy to ASEAN.

With the success of the Bali Concord I which resulted to the Treaty of Amity and Cooperation and Southeast Asia, Indonesia sought of an even higher role for the Bali Concord II in 2003. With aims to make a big leap after the devastating hits of the financial crisis, Indonesia had a vision in establishing a security community in ASEAN. The full extent of the vision included a security community that consists of a peacekeeping force to maintain the security of Southeast Asia, and the promotion of human rights in the region, all written under its 'Draft Plan of Action for a Security Community' (Roberts, 2005, p. 1-3). Indonesia's idea of establishing a Security Community was agreed upon, along with the establishment of an ASEAN Economic and SocioCultural Community. The Security Community was later changed to ASEAN Political and Security Community, and despite not consisting of Indonesia's extensive security ambitions, Indonesia's lingering push was able to create the essential aspects of the ASEAN Community.

The promotion of democratic and human rights values was also evident in the establishment of ASEAN's Intergovernmental Commission on Human Rights. ASEAN gained a vast amount of benefits with Indonesia's 
push for an ASEAN, which respects norms of democracy and human rights. As the act of persistence have led the organization in adopting the ASEAN Charter 2008 in which Indonesia played a great role in making sure it was in align with the respect of human rights and democratic values, it was also a crucial actor in the formation of the ASEAN Declaration of Human Rights adopted in 2012. Indonesia also was at the forefront in the establishment of the ASEAN Intergovernmental Commission on Human Rights inaugurated in 2009, after Indonesia's proposal of creating a form of human rights body in 2007 failed to get positive responses (Sukma, 2012, p. 79-90). The body acts on the basis of consultation to promote and protect human rights, and is considered a major step for ASEAN, an organization that highly regards the values of non-interference and non-intervention towards the domestic policies of a state.

\section{INDONESIA'S LEADERSHIP IN ASEAN: JOKOWI'S POSITION}

The election of Indonesia's Joko Widodo on 20 October 2014, marked significant changes to the political landscape of Indonesia's foreign policy. Joko Widodo unlike previous presidents of Indonesia, had the face of a village man, slowly making his way on the ladder of Indonesia's leadership from becoming a mayor of his hometown Surakarta, elected governor of the state's capital Jakarta, and eventually becoming the number 1 man in Indonesia. But unlike his predecessor Susilo Bambang Yudhoyono, a person who strove the position of Indonesia in global affairs with his vast military experience and leadership, Joko Widodo (well known as Jokowi) was new to the practice of diplomacy and since his election, was highly dependent towards the views and policy inputs of his advisers (Connelly, 2014, p.3-13).

In comparison with SBY and Natalegawa's Dynamic Equilibrium, Indonesia under Jokowi's presidency will be expected to take different courses. Indonesia's Foreign Minister Retno Marsudi in her first Annual policy statement on January 8, 2014, clearly outlined Indonesia's expected foreign policy in the upcoming 5 years of Jokowi's leadership. Retno outlined several basic priorities, including measures to maintain Indonesia's sovereignty, the protection of Indonesian citizens (abroad), and economic diplomacy (The Ministry of Foreign Affairs Republic Indonesia, 2015, 1-7). Retno also reaffirmed the continuation of Indonesia's traditional diplomatic policy of 'Free and Active'. Throughout the first couple of months of his presidency, it has also been clear that Indonesia would be looking upon strengthening its maritime capacity to achieve the aim of Indonesia as a maritime axis/ fulcrum, and regional focus of beyond Asia-Pacific. But the question that surfaces thus is where does ASEAN fit in the picture? Or to a radical extent, will ASEAN still fit in Indonesia's foreign policy priorities?

It would be too fast to assume of Jokowi's upcoming 5-year foreign policy direction based on several months of Indonesia's foreign policy observations. But since the several months of his presidency period, it would be a fair assessment to conclude of Jokowi's lack of interest to continue the intensive regionalism, which was the cornerstone of SBY's foreign policy. Rizal Sukma, the current foreign policy adviser to Jokowi even backs up this sentiment after stating in a public forum in Washington DC that; "We used to say ASEAN is the cornerstone of our foreign policy. Now we change it to a cornerstone of our foreign policy" (Parameswaran, 2014). This section thus aims in countering this growing sentiment by analyzing the high tendencies of Jokowi's policy to still lean upon ASEAN regionalism. The claim will be analyzed through 2 different dimensions; first dimension will be based on the extended leadership role Indonesia will be expected to play following its ostensible rise as a major global power through forums such as the G20. Second dimension analyzes Indonesia's need to return towards its leadership role, based as a policy of reassurance of the peaceful rise of Indonesia.

\subsection{Indonesia's Rising International Profile through The G20: An Extended Leadership Role in ASEAN?}

What will be the consequences of Indonesia's rising International profile? Like any other state currently facing this transition (mainly members states of BRICS), a rising power will face a dilemmatic position of being viewed as both a source of cooperation, and a source of threat. With the current rise of Indonesia, not only will Indonesia be viewed as the state expected to represent ASEAN in higher diplomatic forums, but there will also be a growing need for Indonesia to reaffirm that its rise will not threaten its neighbor states. First and foremost though, it will be crucial to define in what manner Indonesia is currently rising now.

The case of a state being categorized as rising can be based upon myriad amount of factors. The power of a state unlike during the Cold War era, is no longer defined merely on the clout of its military, nor only based on physical attributes of the State. Despite the resource advantage a state would possess, the ability of the state to influence major global decision-making process must also be taken into high consideration. 
Indonesia's transition from a typical Asian middle power towards a major global power can be analyzed based on the combination of its physical features, and the growing influence it has in the global political arena. Indonesia currently holds some impressive statistics being the $4^{\text {th }}$ most populous state, largest Muslim majority, comprises of thousands of islands, and consists of a vast amount of ethnic and religious diversities. Not only that, Indonesia also holds a great strategic position as a founding member of the Non-Alignment Movement, and an influential member of the Organization of Islamic Conference (OIC).

But Indonesia's consistent economic growth is one to be praised most (Garnaut, 2012, p.16). The Organization for Economic Co-operation and Development in 2013 outlined Indonesia's impressive GDP growth that has consistently risen since $2000-2007$ by approximately $5 \%$, and forecasted to continuously rise in the average of $6.4 \%$ from 2013-2017 (OECD, 2013, p. 2). But its economic performance can mainly be seen by the inclusion of Indonesia to the Group of Twenty (G20), consisting of major global economies with aims of promoting international financial stability, which was granted the membership since the formation in 1999. As the only ASEAN state in such an exclusive club. Jim O'neill, the economist who coined the term BRICS in 2001, also predicted how Indonesia will be a major economic power in the $21^{\text {st }}$ century, therefore included included Indonesia into the N11 (Next Eleven), a list of states having high potentials of becoming major world economies (O'neill, 2001, p. 1-15).

Despite not claiming itself as representing ASEAN in the G20, Indonesia throughout the years substantively has been consistent to uphold the aspirations of ASEAN member states. During SBY's presidency, it was evident how Indonesia played a key role in negotiating the inclusion of the ASEAN Chair to attend G20 Summits, that eventually led ASEAN to form the 'ASEAN G-20 Contact Group,' in which the 10 finance ministers of ASEAN will have regular meetings before the G20 Summits to consolidate ASEAN's position (Hermawan, 2011, p. 80-84). Therefore Natalegawa once stated that; "This is what we call diplomacy, that is, how to enhance the capability all together, so we can use ASEAN in G-20 and G-20 in ASEAN" (Hermawan, 2011, p. 82). Indonesia thus plays a key role in surfacing ASEAN's and basically the developing world's global economic concerns in all G20 Summits. This leads to great benefits for ASEAN, as the current Chair of the organization will have the privilege of attending the G20 Summits, representing the views of ASEAN state members.

Indonesia's position representing the voices of developing states, especially members of ASEAN, will further complete its global profile as a representative of the Southeast Asian region. To represent the region in such a high profiled, and geographically influential platform, will provide Indonesia with the case of a completed leadership role in ASEAN, as Indonesia not only has a great say in efforts of conflict management and instilling inputs for institutional establishments, but has and will also play a key leadership role of representing the voices of the organization in a higher diplomatic avenues. As this aim is crucial to further provide foundational basis of the claim that Indonesia is a leader of ASEAN, will Jokowi's presidency see it from the same picture?

The writer is certain of Jokowi's position that would embrace this strategic position in ASEAN. It is evidently clear that the International community perceives Indonesia as the de facto leader of ASEAN, but this representative role of ASEAN members will further complete the status, leading to a stronger political and economic climate of leverage for Indonesia. This role of ASEAN leadership under G20 Summits will most likely be continued under Jokowi's rule, as it provides a great degree of domestic viewer satisfaction, a major factor of why most of his foreign policies (People-based diplomacy, protection of Indonesian workers overseas, etc.) (Saragih, 2014) have been persistent to provide real advantages for the people. The rise of Indonesia's profile through the G20 would form a great sense of domestic pride over the growing influence of Indonesia in the global arena. When it comes to the Indonesian public, executing a certain foreign policy that would attract both the attention and support of the domestic viewers can be considerably strenuous. The sinking of foreign illegal vessels trespassing Indonesian territory has recently gained public attention and support, as it clearly reflects a sign of Indonesia's hard-stance persistence in defending its territorial integrity (Piesse, 2015, p.2-7). Same thing will apply, as the position of leadership in ASEAN would provide praises by the International community, thus a sense of nationalism and pride will be expected to grow among the domestic viewers, something Jokowi craves most of.

\subsection{The Policy of 'Reassurance'}

The dominance, and significant change that Indonesia has brought upon in ASEAN is simply unquestionable. But this wasn't always the case, as the vast majority of ASEAN states have throughout the years, viewed Indonesia's rise as an alarming phenomenon. This sense of fear towards Indonesia can be traced back since Sukarno's rule as the first president of Indonesia. Indonesia that time was already a 
perceived dominant state, which was highly independent towards its foreign policy decision-makings. The policy of Konfrontasi caused a major downfall towards Southeast Asia's trust towards Indonesia, and has since then, Indonesia has failed in tackling that perception despite its various forms of post reformation era, marked with one of the most successful democratization transitions in the history of the region. Indonesia's persistence towards its values further forms this sense of threat, especially during the discussions of the Human Rights Commission proposed by Indonesia. The proposal took 18 long months of intensive negotiations, until in 2009 Indonesia and the other ASEAN members were able to agree to compromise (Sukma, 2012, 80). The last thing that Indonesia would need, is to project their rise as a state, through means that would further hurt the trust that ASEAN member states have tried building upon to.

Jokowi's plans of creating Indonesia as a global maritime axis/ fulcrum though, has recently led its neighboring states to be alert of Indonesia's growing assertive military posture. In an effort to maximize their status as an archipelagic state, Jokowi has raised the need on the safeguard of Indonesia's territorial integrity and securing natural resources in Indonesia's economic exclusive zone (Widodo, Kalla, 2014, p.1214). But the emphasis here does not fall exclusively as a defensive prioritization, but the focus towards becoming a global maritime axis is based on the economic potential and gains that Indonesia can acquire, especially that the aimed axis will incorporate the connectivity between the Pacific Ocean and Indian Ocean (Sebastian, Syailendra, 2014, p.1-3) (Keller, 2014, p. 2-10) (Piesse, 2015, 2-7). Despite thoughts that the concept gives a promising, moreover feasible advantage for Indonesia, reality has reflected otherwise for the early months of Jokowi's presidency. Neighboring states have perceived Indonesia as assertive with its policy of the public sinking of illegal fishing vessels that have operated illegally in Indonesian waters. Despite having full authority to do so, and their practice does not harm any ship crews, this practice can be concluded as an alarming policy for the neighboring ASEAN states. It has been predicted that assertive actions alike may eventually damage the ASEAN solidarity (Parameswaran, 2014), a rather disturbing conclusion in the middle of a greater planned regional integration through the ASEAN Community 2015.

Though gaining massive reputation from the Indonesian domestic viewers, realistically a policy of belligerence like sinking ships of neighboring states will most likely not be able to be sustained. As Jokowi's foreign policy orientation prioritizes the policies that would allure economic benefits for the people of Indonesia, the continuation of such a policy will not be in align with the aspirations of ASEAN. If Jokowi really was serious about attracting economic advantages for the state, concerns must be focused on ASEAN's Economic Community aimed to be fully integrated in 2015. With characteristics of forming a single market and production base, creating a highly competitive economic region, and establishing a region of equitable economic development, Jokowi must refrain from taking any actions that would harm relations with its ASEAN counterparts, which would lead towards issues with the implementation of the 2015 AEC (ASEAN, 2008). With the ASEAN Economic Community coming to a close, Indonesia to be able to gain a significant amount of advantages from the integration, will need to prove of its commitment to regional multilateralism, peaceful rise, and willingness to once again lead ASEAN towards reformations and innovations that would further the position of ASEAN as a global institution. Therefore to be able to achieve economic advantages for his people, it is crucial for Indonesia to reassure its neighbors of its peaceful leadership role in the organization, rather than of its belligerent policies that has recently been evident.

To an even urgent extent, the need to reassure will be needed in facing the upmost threat of China's belligerent rise. Indonesia's policy to engage new cooperation through the Indo-Pacific region will no create any difference to the dominating power that has recently been surfaced by China in the region of Southeast Asia. SBY and Natalegawa's policy of Dynamic Equillibrium was able to respond to its rise very well through the inclusion of other major powers besides China in ASEAN centralized forums and organizations, equaling towards a balance of power in the region (no dominating state). Jokowi though seems blinded of actions he should take to respond towards China's rise, not sure of whether his policies will still be based on ASEAN Centricity or not. This is alarming for Indonesia, as ASEAN centricity, a concept that has positioned ASEAN at the center of all regional arrangements taken in the region (Grant, 2011, p.1-3), is the key to containing a state rising in such an alarming rate. And unlike Indonesia's fellow neighbors in ASEAN, China has throughout the years not only built up its naval capabilities and maritime fleet (Sebastian, 2013, p. 13), but also have shown that it has no hesitation in taking the assertive way of managing a tension, clearly reflected in the disputes with several ASEAN state members over the South China Sea. Indonesia in this particular scenario needs ASEAN, to be able to an extent, contain China's hegemonic power in the region by further continuing the participation of other emerging powers in the ASEAN centralized forums and organizations. But to realize this aim, Indonesia again must reassure its ASEAN counterparts of its prioritization towards regional multilateralism, to be able to continue the collective measures to contain China, which of course is a balanced interest for both Indonesia and ASEAN. 


\section{CONCLUSION}

The foundational basis of various assumptions of Indonesia's leadership role in ASEAN is reflected based on its foreign policies, positioning ASEAN at the core of its interests. Throughout the years, it has been evidently clear on how Indonesia is able to exert its influence, to manage both defining and pressing security concerns correlated with ASEAN member states, and how its persistence towards a more consolidated regionalism system have led to the establishment of key norms and values of the contemporary institutions of ASEAN. Despite apparent shifts of foreign policies by the newly elected Joko Widodo, with high emphasis upon foreign policies to establish Indonesia as a global maritime axis and foreign policies benefiting the domestic population, a shift of its leadership role in ASEAN is highly unlikely. Indonesia's ostensible rise both in the region and globally will have to be met with the continuation of its leadership roles in ASEAN, aimed in solidifying its influence in both the G20 and reassure its position of being a non-assertive state in the region of Southeast Asia. Eventually, Indonesia's past and future interactions with ASEAN will be based on a balanced consideration of benefits gained from the cooperation, making sure that any roles taken will be pertinent towards the benefits gained with the interaction itself.

\section{REFERENCE LIST}

Anwar, Dewi Fortuna. (1994). Indonesia in ASEAN: Foreign Policy and Regionalism. New York: St. Martin's Press.

Anwar, Dewi Fortuna. (2013). "Reinvention in Indonesia's Foreign Policy Strategy". East Asia Forum Quarterly: Economics, Politics, and Public Policy in East Asia and the Pacific, 5 (4).

ASEAN. (1971). Zone of Peace, Freedom, and Neutrality Declaration: Adopted by the Foreign Ministers at the Special ASEAN Foreign Ministers Meeting. Kuala Lumpur: Association of Southeast Asian Nations.

ASEAN. (2002). Declaration on the Conduct of Parties in the South China Sea: Adopted by the Foreign Ministers of ASEAN and the People's Republic of China at the $8^{\text {th }}$ ASEAN Summit. Phnom Penh: Association of Southeast Asian Nations.

ASEAN. (2008). ASEAN Economic Community Blueprint. Singapore: Association of Southeast Asian Nations.

Borzel, Tanja A., Goltermann, Lukas, Mathis, Lohaus, \& Striebinger, Kai. (2012). Roads to Regionalism, Genesis, Design, and Effects of Regional Organizations. UK: Ashgate Publishing Limited.

Connelly, Aaron L. (2014). "Indonesian Foreign Policy under President Jokowi". Lowy Institute for International Policy, October.

Emmers, Ralf. (2014). "Indonesia's Role in ASEAN: A Case of Incomplete and Sectorial Leadership". The Pacific Review. 27 (4).

Garnaut R. (2012). "Indonesia in the New World Balance". In Reid, Anthony (Ed.) Indonesia Rising: The Repositioning of Asia's Third Giant. Singapore: Institute of Southeast Asian Studies.

Grant, Richard. (2011). "Regional Institutions Following EAS 2011”. Asia:NZ Foundation, December.

Hermawan, Yulius P. (2011). "G-20 Research Project: The Role of Indonesia in the G-20: Background, Role and Objectives of Indonesia's Membership". Friedrich Ebert Stiftung Indonesia Office in Cooperation with the Department of International Relations, Parahyangan University, 80-84.

Karim, Mohd. Aminul. (2013). "The South China Sea Disputes: Is High Politics Overtaking?". Pacific Focus Inha Journal of International Studies, 28 (1).

Keohane, Robert O. (1984). After Hegemony, Cooperation and Discord in the World Political Economy. Princeton: Princeton University Press.

Kindleberger, Charles. (1979). The World in Depression, 1929-1939. Los Angeles: University of California Press.

Kumar, Rajesh. (1997). Non-Alignment Policy of Indonesia. Jakarta: Centre for Strategic and International Studies.

Liow, Joseph Chinyong. (1995). Dictionary of the Modern Politics of Southeast Asia: $4^{\text {th }}$ edition. NY: 
Routledge.

Nabbs-keller, Greta. (2014). "Strategic Centrality, Political Uncertainty: Prospects for Defense and Security Under President Joko Widodo". Perth USAsia Centre United.

Norkevičius, Mindaugas. (2014). "Regional Institutionalism in Southeast Asia”. Societal Studies. 6 (1).

O'neill, Jim. (2001). "Building Better Global Economic BRICs". Goldhman Sachs Global Economic Paper. 66.

OECD. (2013). "Structural Policy Country Notes: Indonesia". Southeast Asian Economic Outlook 2013, Organization for Economic Cooperation and Development, 2.

Parameswaran, Prashanth. (2014). "Is Indonesia Turning Away from ASEAN Under Jokowi? Early Signs Point to a far more Bilateral, Domestic Oriented Foreign Policy". The Diplomat, accessed 05 February 2014. http://thediplomat.com/2014/12/is-indonesia-turning-away-from-asean-under-jokowi/.

Piesse, Mervyn. (2015). "Indonesian Foreign Policy and the Regional Impact of its Maritime Doctrine". Future Directions International, January.

Piesse, Mervyn. (2015). "The Indonesian Maritime Doctrine: Realizing the Potential of the Ocean". Future Directions International, Strategic Analysis Paper, January.

Poling, Gregory. (2013). "Dynamic Equilibrium: Indonesia's Blueprint for a $21^{\text {st }}$ Century Asia Pacific". Center for Strategic and International Studies, 4 (5).

Rattanasevee, Pattharapong. (2014). "Leadership in ASEAN: The Role of Indonesia Reconsidered". Asian Journal of Political Science, 22 (2).

Roberts, Christopher. (2005). "The 'ASEAN Charter': A Crossroads for the Region?". IDSS Commentaries, 2005.

Saragih, Bagus BT. (2015). "Jokowi on 'People-Based Diplomacy”. The Jakarta Post. Accessed 17 February 2015. http://www.thejakartapost.com/news/2014/09/10/jokowi-people-based-diplomacy.html.

Sebastian, Leonard C. (2013). "Indonesia's Dynamic Equilibrium and ASEAN Centrality". The NIDS International Symposium, November.

Sebastian, Leonard C. \& Syailendra, Emirza Adi. (2014). "Jokowi's "Look West" Foreign Policy: Expanding Indonesia's Sphere of Influence”. RSIS Commentary, 207.

Sukma, Rizal. (2012). "Indonesian Foreign Policy: Domestic Politics and International Posture: Constraints and Possibilities". In Reid, Anthony (Ed.) Indonesia Rising: The Repositioning of Asia's Third Giant. Singapore: Institute of Southeast Asian Studies, 79-85.

Suryadinata, Leo. (1996). Indonesia's Foreign Policy Under Suharto, Aspiring to International Leadership. Singapore: Times Academic Press.

The Ministry of Foreign Affairs Republic Indonesia. (2015). Annual Press Statement Minister for Foreign Affairs Republic of Indonesia, 8 January 2015, 1-7.

Traviss, Alexander C. (2012). "Temple of Preah Vihear: Lessons on Provisional Measures". Chicago Journal of International Law, 13 (1).

Widodo, Joko \& Kalla, Jusuf. (2014). Berdaulat dalam bidang politik, berdikari dalam bidang ekonomi dan berkepribadiaan dalam kebudayaan, Jokowi-Jusuf Kalla 2014, Jalan Perubahan Untuk Indonesia Yang Berdaulat, Mandiri Dan Berkepribadian: Visi, Misi Dan Program Aksi. Jakarta, May 2014.

Widyaningsih, Erlina \& Roberts, Christopher B. (2014). "Indonesia in ASEAN: Mediation, Leadership, and Extra-Mural Diplomacy". National Security College Issue Brief, May. 